\title{
Antiperinuclear factor, a marker autoantibody for rheumatoid arthritis: colocalisation of the perinuclear factor and profilaggrin
}

\author{
R M A Hoet, A M Th Boerbooms, M Arends, D J Ruiter, W J van Venrooij
}

\begin{abstract}
The antiperinuclear factor, an autoantibody specific for rheumatoid arthritis, was found in $51 / 63(81 \%)$ patients with rheumatoid arthritis by indirect immunofluorescence on human buccal mucosa cells. The sensitivity of the antiperinuclear factor test was increased by pretreating the buccal mucosa cells with $0.5 \%$ Triton-X100. The specificity of the test for rheumatoid arthritis as compared with control serum samples was maintained.

The localisation of the perinuclear factor in the keratohyalin granules of the buccal mucosa cells was verified by immunoelectron microscopy. The perinuclear factor was found to be an insoluble protein whose antigenicity was sensitive to various fixation procedures. In serum samples from patients with rheumatoid arthritis there was a positive correlation between the presence of antiperinuclear factor and the presence of the so called antikeratin antibodies as detected by immunofluorescence on unfixed rat oesophagus cryostat sections. No relation was found between the presence of the perinuclear factor and either the rheumatoid factor, Epstein-Barr virus components, or any cytokeratin. By double immunofluorescence an exact colocalisation of the perinuclear factor and profilaggrin was found. Although the precise biochemical identity of the perinuclear factor remains unclear, our results suggest that it is a protein only present in the fully differentiated squamous epithelial cell layer.
\end{abstract}

Department of Biochemistry, University of Nijmegen, PO Box 9101, $6500 \mathrm{HB}$ Nijmegen, The Netherlands R M A Hoet

W J van Venrooij

Department of Internal

Medicine, Section of

Rheumatology,

University Hospital

Nijmegen,

The Netherlands

A M Th Boerbooms

Department of

Pathology, University

Hospital Nijmegen,

The Netherlands

$M$ Arends

D J Ruiter

Correspondence to:

Dr Hoet.

Accepted for publication

14 September 1990
Serum samples from patients with connective tissue diseases often contain antibodies against cellular components. ${ }^{1}$ In some cases the presence of these autoantibodies is specifically associated with a certain syndrome or disease, and therefore useful as diagnostic marker. Good examples of such markers are anti-Sm antibodies in systemic lupus erythematosus and anti-Jo-1 in patients with polymyositis. ${ }^{1}$ Serological support for the diagnosis of rheumatoid arthritis is not well established and mainly based on the presence of rheumatoid factors. Rheumatoid toid arthritis, however, and can also be found in serum samples from patients with other (autoimmune) diseases and even in healthy subjects. ${ }^{2}$ Therefore the availability of another specific serological marker for rheumatoid arthritis would be useful.

Three other antibody specificities have been described as being specific for rheumatoid arthritis, all three directed against different factor is not present in all patients with rheuma- components of epithelial cells-namely, antibodies against intermediate filaments in cultured cells, antibodies against a keratin-like component in rat oesophageal epithelium, and the antiperinuclear factor, consisting of antibodies directed against a component in human buccal mucosa cells.

All three specificities are detectable by indirect immunofluorescence. Antibodies against intermediate filaments in rheumatoid serum samples have specificity for the intermediate filament proteins vimentin or cytokeratin, or both, in cultured cells and are mostly of the IgM class. ${ }^{3-5}$ Antibodies against vimentin have been found in $54-80 \%$ of patients with rheumatoid arthritis, ${ }^{346-8}$ and antibodies against cytokeratin in $31-40 \%$ of such patients. ${ }^{348}$ Antibodies against intermediate filaments, however, are not particularly specific for rheumatoid arthritis and are often present in other diseases also, ${ }^{34910}$ and have even been found in $14-63 \%$ of healthy subjects. ${ }^{3411}$

Antibodies against keratin, detectable by immunofluorescence on rat oesophagus tissue, and first described in 1979 by Young and coworkers, ${ }^{12}$ are found in $36-69 \%$ of rheumatoid serum samples and in only $0-4 \cdot 2 \%$ of healthy control serum samples. ${ }^{4} 812-18$ These antibodies are predominantly of the IgG class and can also be found in synovial fluid of patients with rheumatoid arthritis. ${ }^{14}$

The antiperinuclear factor was originally described by Nienhuis and collaborators, ${ }^{19}$ who demonstrated its high specificity for rheumatoid arthritis. The antibodies, mostly of the IgG type, are directed against a protein in the $0.5-4$ $\mu \mathrm{m}$ spherical shaped keratohyalin granules in the cytoplasm of buccal mucosa cells and are found in $48-86 \%$ of serum samples ${ }^{19-32}$ and synovial fluids from patients with rheumatoid arthritis. ${ }^{19}$ Westgeest et al found that antiperinuclear factor titres correlate with the severity of disease, ${ }^{21}$ and this is most clearly seen in patients without the rheumatoid factor. An increased prevalence of antiperinuclear factor has been described in certain other syndromes. $22-2531$

The major drawback of the antiperinuclear factor immunofluorescence test is the nature of the substrate. Most authors report that only a small percentage of buccal mucosa cell donors have antigen present in a satisfactory amount. ${ }^{16} 2226-28$

In this study we modified and improved the sensitivity of the antiperinuclear factor test and reassessed its specificity. Additionally, new data on the localisation and characterisation of the perinuclear factor are presented, and the pos- 
sible relation between perinuclear factor and other antibody specificities was investigated.

\section{Materials and methods \\ PATIENTS SERUM SAMPLES \\ Most serum samples were obtained from patients seen at the department of rheumatology and internal medicine of the Academic Hospital, Nijmegen. Diagnoses were reached as described by de Rooij et al. ${ }^{33}$ Serum samples from patients with Lyme's disease were kindly provided by $\mathrm{J}$ Hardin (Yale University, New Haven, USA). All samples were stored at $-70^{\circ} \mathrm{C}$ until required for analysis.}

\section{MONOCLONAL AND POLYCLONAL ANTIBODIES}

The following monoclonal $(\mathrm{m})$ and polyclonal (p) antibodies were kindly provided by Dr F Ramaekers: RCK102 (m) recognising cytokeratin (ck) 5 and $8^{34}$; RCK 105 (m) recognising ck $7^{34}$; RGE53 (m) recognising ck $18^{35}$; RKSE60 (m) recognising ck 10 ${ }^{36}$; RV202 (m) recognising vimentin. ${ }^{34} 6 \mathrm{~B} 10(\mathrm{~m})$ recognising ck 4 , and $2 \mathrm{D} 7(\mathrm{~m})$ recognising ck 13 were provided by $\operatorname{Dr} \mathrm{G}$ van Muijen. ${ }^{37}$ Monoclonal antibody 41 CC4 directed against lamins A, B, and $C$ was a kind gift of Dr J Warren. ${ }^{38}$ AntiEBV-VCA (m) (Epstein-Barr virus viral capsid antigen), anti-EBV-EA(D)(m) (Epstein-Barr virus early antigen diffuse component), and anti-P62 (p) (human P62 cross reacting with Epstein-Barr nuclear antigen-1) were kindly provided by Dr P J W Venables (London). AKH1, a monoclonal antibody against human profilaggrin $(>400 \mathrm{kD})$ and filaggrin $(37 \mathrm{kD})$, and $\mathrm{AKH} 2$, a monoclonal antibody reacting with an unidentified component of keratohyalin granules were kindly provided by Dr B Dale. ${ }^{39}$ Polyclonal serum anti-54 kD, recognising a histidine-rich protein of rat granular cells was kindly provided by Dr K Fukuyama, ${ }^{40}$ and monoclonal 3F6-6 (anti-rat filaggrin) was a gift of Dr I A Bernstein. ${ }^{41}$ Other antibodies were purchased from ICN Immuno Biologicals (monoclonal $\mathrm{AE}^{42}$ reacting with ck $1,2,10$, 11 , and with filaggrin), Dakopatts (A575, rabbit serum against human epidermal cytokeratin), and Biomakor (K8.12, monoclonal against ck 13 and $16^{43}$ ). Monoclonal antibodies against $U$ snRNP proteins were obtained from Drs S O Hoch $\left(2 \cdot 73^{44}\right)$, J Steitz $\left(Y 12^{45}\right)$, and W Habets $\left(9 \mathrm{~A} 9\right.$ and $\left.4 \mathrm{G}^{46}\right)$. D106 is a human antibody directed against topoisomerase I obtained from a patient with scleroderma.

\section{ANTIGENIC SUBSTRATE FOR THE \\ ANTIPERINUCLEAR FACTOR}

Epithelial cells from human buccal mucosa from a positive donor were scraped from the inside of the cheek with a piece of foam plastic and brought into suspension by rinsing the foam with phosphate buffered saline (PBS), $\mathrm{pH}$ $7 \cdot 4$. The cell suspension was washed twice with PBS, once with $0.5 \%$ Triton-X100 in PBS, and again with PBS (five minutes' centrifugation at $800 \mathrm{~g}$ ). A cell suspension was made in PBS and the cells were either spun down on microscopical slides with a cytospin centrifuge or were transferred dropwise to microscopical slides and after air drying immediately used as substrate in the immunofluorescence test $(100-400$ cells per slide). Slides could be stored for up to two weeks at $-70^{\circ} \mathrm{C}$.

\section{DETECTION OF ANTIPERINUCLEAR FACTOR BY} IMMUNOFLUORESCENCE

The slides with buccal mucosa cells were incubated with the serum (diluted 1:5 with PBS, cleared by five minutes' centrifugation at $13000 \mathrm{~g}$ ) for 90 minutes in a $100 \%$ humid atmosphere. The preparations were washed in PBS $(3 \times 10$ minutes) and incubated for 30 minutes with purified fluorescein isothiocyanate labelled rabbit antibody against human IgM, IgG, and IgA (Dakopatts F200, dilution 1:100). After extensive washing with PBS $(3 \times 10$ minutes) the preparations were mounted in a glycerol/PBS (1:1) solution with ethidium bromide $(0.5 \mu \mathrm{g} / \mathrm{ml})$ as a nuclear counterstain. The slides were read under an Olympus fluorescence microscope.

\section{DETECTION OF ANTIKERATIN ANTIBODIES BY} IMMUNOFLUORESCENCE

Detection of antikeratin antibodies was performed essentially as described by Young and coworkers, ${ }^{12}$ with a few modifications. Rat oesophagus cryostat sections were incubated for five minutes in $0.5 \%$ Triton-X100 in PBS, and then washed for five minutes in PBS before incubation with the serum. Serum samples were tested in a dilution of $1: 10$, and fluorescein isothiocyanate labelled rabbit antibody against human IgG, IgM, and IgA (Dakopatts F200; dilution $1: 100$ ) was used as conjugate.

\section{RHEUMATOID FACTOR}

Serum samples were tested for rheumatoid factor by the medical microbiology department of the Academic Hospital, Nijmegen, using the Waaler-Rose and latex fixation tests. These agglutination assays were performed as a microtitre modification. ${ }^{47}$ All patients scored as rheumatoid factor negative had a maximum titre of only $1 / 32$ (Waaler-Rose test) or 1/40 (latex fixation test).

\section{PREPARATION OF CELL EXTRACTS}

Extracts of human foreskin epidermis were prepared as described by Fleckman et al for human epidermis, ${ }^{48}$ and finally dissolved in $\mathrm{S}$ buffer (8 M urea, $50 \mathrm{mM}$ TRIS. $\mathrm{HCl}(7 \cdot 6), 100$ $\mathrm{mM}$ dithiothreitol, 0.13 M 2-mercaptoethanol, $100 \mu \mathrm{g} / \mathrm{ml}$ phenylmethylsulphonyl fluoride, 100 $\mu \mathrm{g} / \mathrm{ml}$ aprotinin). After centrifugation (10 minutes, $13000 \mathrm{~g}$ ) $1 / 4$ volume of $4 \times$ sodium dodecyl sulphate sample buffer ${ }^{49}$ was added. Buccal mucosa cells were first treated with $0.5 \%$ Triton-X100 in PBS and after centrifugation (10 minutes at $800 \mathrm{~g}$ ) dissolved in $S$ buffer. Finally, 1/4 volume $4 \times$ sodium dodecyl sulphate sample buffer ${ }^{49}$ was added. 
GEL ELECTROPHORESIS AND IMMUNOBLOTTING Sodium dodecyl sulphate/polyacrylamide gel electrophoresis, transfer of proteins from polyacrylamide gels onto nitrocellulose sheets, and detection of the antigens on the blots were performed as described. 5051

\section{IMMUNOELECTRON MICROSCOPY}

Buccal mucosa cells were spun down on microscopic slides coated with a plastic sheet (Melinex, ICI, Herts, UK) and immediately fixed in sodium cacodylate buffered $1 \%$ paraformaldehyde for one minute at $4^{\circ} \mathrm{C}$. After rinsing the cells for 10 minutes in PBS the endogenous peroxidase activity was blocked with $0.9 \% \mathrm{H}_{2} \mathrm{O}_{2}$ in PBS for five minutes, washed for 10 minutes with PBS, preincubated for 20 minutes with $10 \%$ normal rabbit serum, immediately followed by one hour's incubation with a rheumatoid serum sample containing antiperinuclear factor (diluted 1:50). Extensive washing with PBS ( $3 \times 5$ minutes) was followed by 30 minutes' incubation with peroxidase conjugated rabbit antihuman IgG (Dakopatts, diluted 1:80). After three additional five minute washing steps with PBS the cells were stained for five minutes with $0.65 \%$ imidazole in PBS with $0 \cdot 0015 \% \mathrm{H}_{2} \mathrm{O}_{2}$. The staining was quenched in water and the cells were postfixed for 10 minutes in $2.5 \%$ glutaraldehyde in $0.1 \mathrm{M}$ sodium cacodylate buffer. After rinsing for 10 minutes in $0.1 \mathrm{M}$ sodium cacodylate buffer the cells were treated for 30 minutes with $1 \% \mathrm{OsO}_{4}$ in Palade buffer ( $70 \mathrm{mM}$ sodium acetate, 70 $\mathrm{mM}$ sodium-veronal, $\mathrm{pH} 7 \cdot 4$ ), washed for $2 \times 10$ minutes in Palade buffer, and after dehydration with successively ethanol $70 \%, 90 \%, 100 \%$ and propylene oxide, embedded in Epon 812. Thereafter a 'pop-off method was used essentially as described by Ruiter et al. ${ }^{52}$ Semi-thin sections were light microscopically examined for the presence of immunostaining. Ultrathin sections were made from areas selected, not contrasted, and examined and photographed on a Philips 300 electron microscope at $\mathbf{4 0 ~ k V}$.

\section{Results}

\section{THE ANTIPERINUCLEAR FACTOR TEST AND ITS} RELIABILITY

For detection of the antiperinuclear factor most investigators ${ }^{19-32}$ have used unfixed buccal mucosa cells because fixatives have a negative effect on the antigenicity of the perinuclear factor. We modified the antiperinuclear factor test by pretreating the cells with $0.5 \%$ Triton$\mathrm{X} 100$ in PBS. This pretreatment increased the percentage of rheumatoid patients with the antiperinuclear factor from $73 \%(46 / 63)$ to $81 \%$ (51/63), whereas the percentage of healthy controls remained unchanged $(6 \%(3 / 51)$ in both cases). In our hands the modified test was not only more sensitive but also more reproducible. Figure 1 shows a typical reaction of a buccal mucosa cell with a serum sample positive for antiperinuclear factor. Table 1 summarises the percentages of serum samples positive for antiperinuclear factor from patients with rheumatoid arthritis and healthy subjects (controls) described in other reports and gives our own data obtained with the modified antiperinuclear factor test. The sensitivity of antiperinuclear factor for rheumatoid arthritis was $\mathbf{8 1 \%}$. Investigation of the specificity of the antiperinuclear factor (table 2) showed that the prevalence of antiperinuclear factor is also somewhat higher in serum samples from patients with systemic lupus erythematosus (21\%), systemic sclerosis (26\%), and Siögren's syndrome (29\%).

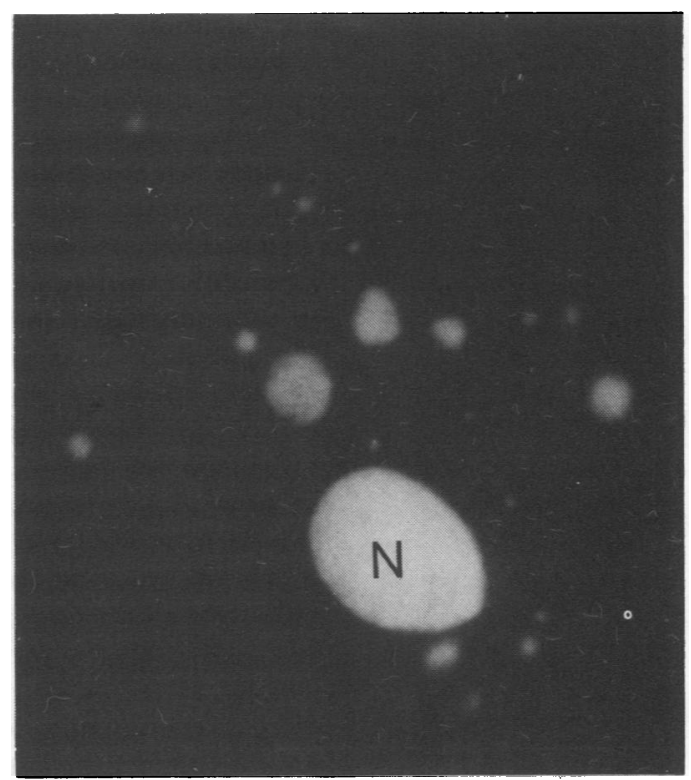

Figure 1 Immunofluorescent staining of a buccal mucosa cell with an antiperinuclear factor positive serum sample from a patient with rheumatoid arthritis. Immunofluorescence was carried out as described in 'Materials and methods'. The nucleus $(N)$ was counterstained with $0.5 \mu \mathrm{g} / \mathrm{ml}$ ethidium bromide.

Table 1 Percentages of serum samples positive for añtiperinuclear factor in patients with rheumatoid arthritis and healthy controls summarised from published reports

\begin{tabular}{|c|c|c|c|c|c|c|}
\hline First author & Year/ref & $\begin{array}{l}\text { Rheumatoid } \\
\text { serum } \\
\text { samples (n) }\end{array}$ & $\begin{array}{l}\underset{(\%)}{A P F^{*}}(+) \\
\end{array}$ & $\begin{array}{l}\text { Control } \\
\text { serum } \\
\text { samples (n) }\end{array}$ & $\underset{(\%)}{A P F(+)}$ & $\begin{array}{l}\text { Serum } \\
\text { dilution }\end{array}$ \\
\hline $\begin{array}{l}\text { Nienhuis } \\
\text { Marmont } \\
\text { Sondag-Tschroots } \\
\text { Smit } \\
\text { Johnson } \\
\text { Youinou } \\
\text { Kataaha } \\
\text { Westgeest } \\
\text { Janssens } \\
\text { Our own results }\end{array}$ & $\begin{array}{l}1964 / 19 \\
1967 / 29 \\
1979 / 22 \\
1980 / 20 \\
1981 / 16 \\
1983 / 26 \\
1985 / 4 \\
1987 / 21 \\
1988 / 28 \\
\text { This paper }\end{array}$ & $\begin{array}{r}105 \\
100 \\
103 \\
97 \\
102 \\
178 \\
72 \\
132 \\
127 \\
63\end{array}$ & $\begin{array}{l}49 \\
51 \\
78 \\
79 \\
81(92) \dagger \\
68 \\
74 \\
52 \\
86 \\
81\end{array}$ & $\begin{array}{l}431 \\
50 \\
111 \\
96 \\
60 \\
67 / 76 \ddagger \\
93 \\
54 \\
2625 \\
51\end{array}$ & $\begin{array}{c}<1 \\
0 \\
4 \\
4 \\
14(20) \dagger \\
7 / 12 \ddagger \\
3 \\
2 \\
45 \\
6\end{array}$ & $\begin{array}{l}\text { Undiluted } \\
\text { Undiluted } \\
1: 5 \\
1: 5 \\
1: 5 \\
1: 5 \\
1: 5 \\
\text { Undiluted } \\
1: 5 \\
1: 5\end{array}$ \\
\hline
\end{tabular}

*APF=antiperinuclear factor.

The value in parentheses also include weak positive serum samples.

Aged $<60 />60$ years.

SOther autoimmune diseases. 
Table 2 Specificity and sensitivity of the antiperinuclear factor

\begin{tabular}{lll}
\hline Disease* $^{*}$ & $\begin{array}{l}\text { Number } \\
\text { of serum } \\
\text { samples }\end{array}$ & $\begin{array}{l}A P F^{*}(+) \\
\text { serum samples } \\
(\%)\end{array}$ \\
\hline $\begin{array}{ll}\text { Rheumatoid arthritis } \\
\text { Systemic lupus erythematosus }\end{array}$ & 63 & 81 \\
Mixed connective tissue disease & 21 & 21 \\
Undifferentiated connective & 20 & 5 \\
tissue disease & 34 & 29 \\
Sjögren's syndrome & 34 & 26 \\
Systemic sclerosis & 26 & 4 \\
Lyme's disease & 51 & 6 \\
Healthy controls & & \\
\hline
\end{tabular}

${ }^{*}$ Diagnoses were reached according to published criteria. ${ }^{33}$

In contrast with other studies we found that at least $70 \%(35 / 50)$ of normal healthy subjects (aged 18-35 years) have the perinuclear factor in their buccal mucosa cells and therefore are potential positive donors. To test possible qualitative differences in antigen composition between different positive donors 10 of them were screened with 10 positive rheumatoid serum samples. Each of the 10 donors reacted with all positive serum samples (data not shown). The percentage of cells that were stained varied between donors, depending on the titre of the serum, indicating that there are only quantitative differences in the amount of antigen among the different donors.

POSSIBLE RELATION BETWEEN ANTIPERINUCLEAR FACTOR, RHEUMATOID FACTOR, AND ANTIKERATIN ANTIBODIES

It has been suggested that the antiperinuclear factor might be a kind of rheumatoid factor. ${ }^{32}$ This possibility was tested by determining the correlation between rheumatoid factor and antiperinuclear factor (table 3). Although the percentage of serum samples positive for rheumatoid factor among patients with rheumatoid arthritis (83\%) was comparable with the percentage positive for antiperinuclear factor $(81 \%)$, there was no complete overlap. More than $11 \%$ of the serum samples without antiperinuclear factor had the rheumatoid factor, whereas more than $6 \%$ without rheumatoid factor contained the antiperinuclear factor. So it seems unlikely that the antiperinuclear factor is some kind of rheumatoid factor.

Serum samples with and without the anti-

Table 3 Correlation between rheumatoid factor and antiperinuclear factor in 63 patients with rhewmatoid arthritis. Results are given as number of patients (percentage of the 63 patients)

\begin{tabular}{lccc}
\hline $\begin{array}{l}\text { Antiperinuclear factor } \\
(\text { No }(\%))\end{array}$ & \multicolumn{3}{l}{ Rheumatoid factor $($ No (\%)) } \\
\cline { 2 - 4 } & $\begin{array}{l}+/- \\
52(83)\end{array}$ & $\begin{array}{l}+(6) \\
7(11)\end{array}$ \\
\hline$++(81)$ & $44(70)$ & $3(5)$ & $4(6)$ \\
$+1-$ & $1(2)$ & $0(0)$ & $1(2)$ \\
$2(3)$ & $7(11)$ & $1(2)$ & $2(3)$ \\
\hline $10(16)$ & &
\end{tabular}

Antiperinuclear factor and rheumatoid factor were determined as described in the 'Materials and methods' section.

described in the 'Materials and methods section. The correlation between antiperinuclear factor and rheurmatoid with Yates's correction. $\chi^{2}=1 \cdot 41,0.25>p>0.1$ perinuclear factor from patients with rheumatoid arthritis were also screened for the presence of antikeratin antibodies (table 4). Although the test for antikeratin antibodies is somewhat less sensitive than the antiperinuclear factor test, the simultaneous occurrence of both antibody activities in serum samples from patients with rheumatoid arthritis was striking.

LOCALISATION AND BIOCHEMICAL NATURE OF THE PERINUCLEAR FACTOR

Light microscopic techniques have shown that the perinuclear factor is located in the keratohyalin granules. ${ }^{20}$ Nothing is known about the intragranular distribution of the antigen, however. Using an immunoelectron microscopical approach we established that the antigen is present throughout the keratohyalin granule (fig 2). The chemical nature of the antigen was investigated by testing the effect of several chemical and enzymatic treatments on it. After these treatments a normal antiperinuclear factor immunofluorescence test was performed. The results (table 5) indicate that the perinuclear factor is an insoluble protein, sensitive to freezing and thawing. Fixation of the cells with methanol or acetone partly destroys antigenicity. Treatment of the cells with Triton-X100 not only retains the perinuclear factor but intensifies the immunofluorescence staining.

Table 6 shows the results of experiments with various specific antibodies that were tested on

Table 4 Correlation between the so called antikeratin antibodies and the antiperinuclear factor in 46 patients with rheumatoid arthritis. Results are given as number of patients (percentage of the 46 patients)

\begin{tabular}{|c|c|c|c|}
\hline \multirow{2}{*}{$\begin{array}{l}\text { Antiperinuclear factor } \\
(\text { No }(\%))\end{array}$} & \multicolumn{3}{|c|}{ Antikeratin antibodies (No (\%)) } \\
\hline & $\stackrel{+}{25}(54)$ & $\begin{array}{l}+1- \\
12(26)\end{array}$ & $\overline{9}(20)$ \\
\hline $\begin{array}{l}+ \\
37(80) \\
+/-\end{array}$ & $24(52)$ & $10(22)$ & $3(7)$ \\
\hline $5(11)$ & $1(2)$ & $1(2)$ & $3(7)$ \\
\hline $4(9)$ & $0(0)$ & $1(2)$ & $3(7)$ \\
\hline
\end{tabular}

Correlation between antiperinuclear factor and antikeratin antibodies $\left(+v+1-\right.$ and - results) was calculated with the $\chi^{2^{\circ}}$ test with Yates's correction. $\chi^{2}=6.11,0.025>p>0.01$.

Table 5 Effect of different treatments on the antigenicity of the perinuclear factor

\begin{tabular}{|c|c|}
\hline Treatment & $\begin{array}{l}\text { Antiperinuclear } \\
\text { factor after } \\
\text { treatment }\end{array}$ \\
\hline $\begin{array}{l}\text { No treatment } \\
\text { Trypsin }\left(0.35 \% ; 1 \mathrm{~h}, 37^{\circ} \mathrm{C}\right) \\
\text { RNase A }\left(100 \mu \mathrm{g} / \mathrm{ml} ; 1 \mathrm{~h}, 37^{\circ} \mathrm{C}\right) \\
\text { DNase I }\left(100 \mu \mathrm{g} / \mathrm{ml} ; \mathrm{h}, 37^{\circ} \mathrm{C}\right) \\
\text { Hyaluronidase }\left(0.1 \mathrm{mg} / \mathrm{ml} ; 1 \mathrm{~h}, 37^{\circ} \mathrm{C}\right) \\
\text { Chondroitinase } \mathrm{ABC}\left(1 \mathrm{U} / \mathrm{ml} ; 1 \mathrm{~h}, 37^{\circ} \mathrm{C}\right) \\
\text { Triton-X100 }\left(0.5 \% ; 5 \mathrm{~min}, 0^{\circ} \mathrm{C}\right) \\
\text { Sodium desoxycholate }(0.5 \%) / \mathrm{NP}-40(1 \%) \\
\left(5 \mathrm{~min}, 0^{\circ} \mathrm{C}\right) \\
\text { Urea }\left(2 \mathrm{M} ; 5 \mathrm{~min}, 0^{\circ} \mathrm{C}\right) \\
\text { Urea }\left(4 \mathrm{M} ; 5 \mathrm{~min}, 0^{\circ} \mathrm{C}\right) \\
\left.\text { Urea (8 M; } 5 \mathrm{~min}, 0^{\circ} \mathrm{C}\right) \\
\text { Rapid freezing } / \text { thawing }(3 \text { times) } \\
\text { Methanol }\left(5 \mathrm{~min},-20^{\circ} \mathrm{C}\right) \\
\text { Acetone }\left(5 \mathrm{~min}, 4^{\circ} \mathrm{C}\right)\end{array}$ & $\begin{array}{l}+ \\
-^{*} \\
+ \\
+ \\
+ \\
+ \\
++ \\
+ \\
+ \\
+ \\
\pm^{*} \\
{ }^{* *} \\
\mathbf{w}++ \\
\mathbf{w}+ \\
\mathbf{w}+\end{array}$ \\
\hline
\end{tabular}


buccal mucosa cells and rat oesophagus cryostat sections. Rat oesophagus epithelial layer gave a positive immunofluorescence staining with monoclonal antibodies 6B10, 2D7, and K8.12, which all recognise cytokeratins 4 and 13 known to be specifically present in squamous epithelium. These monoclonal antibodies (6B10, 2D7, K8.12) also gave a specific immunostaining with a rat oesophagus extract on western blot, whereas we could not identify a specific immunostaining with serum samples with and without antikeratin antibodies (data not shown).

The keratohyalin granules of the buccal mucosa cells did not react with polyclonal and monoclonal antibodies against intermediate filaments (cytokeratins, lamins, vimentin), Epstein-Barr virus proteins, and U snRNPs. In fact, only polyclonal and monoclonal antibodies against (pro)filaggrin gave a positive staining of the keratohyalin granules. A monoclonal antibody against human profilaggrin AKH1 was then used in a double immunofluorescence test with a number of serum samples strongly

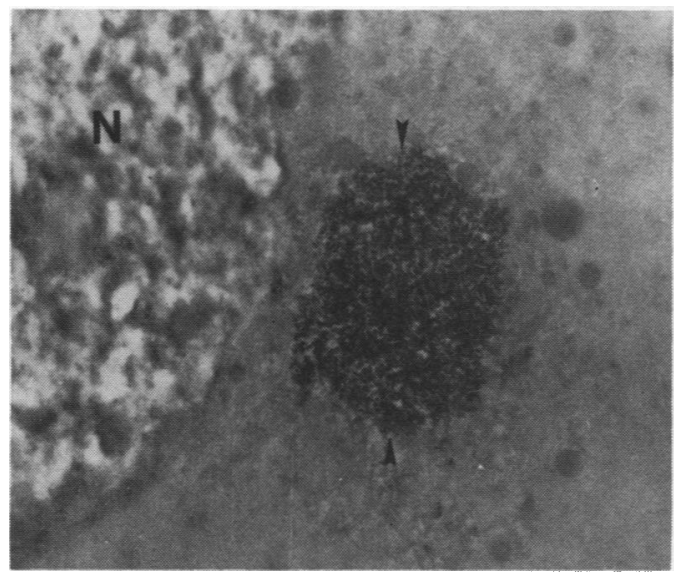

Figure 2 Localisation of the perimuclear factor by imamunoelectron microscopy, as described in 'Materials and methods'. The keratohyalin granule (arrowheads) is more or less homogeneously stained with antiperinuclear factor positive rheumatoid serum $E 10 . N=$ nucleus.

Table 6 Reactivity of buccal mucosa cells and rat oesophagus sections with various monoclonal and polyclonal antibodies

\begin{tabular}{|c|c|c|c|}
\hline Antibody code & Antigen & $A P F^{*}$ & $A K A^{*}$ \\
\hline $\begin{array}{l}\text { a-EBV-VCA (m)* } \\
\alpha-E B V-D(m) \\
\alpha-P 62(p)^{*} \\
\text { RCK102 (m) } \\
\text { A575 (p) } \\
\text { RGE53 (m) } \\
\text { RKSE60 (m) } \\
6 B 10(m) \\
2 D 7(m) \\
\text { RCK105 (m) } \\
\text { K8.12 (m) } \\
\text { RV202 (m) } \\
41 C C 4(\mathrm{~m}) \\
\text { 9A9 (m) } \\
\text { 4G3 (m) } \\
\text { Y12 (m) } \\
2.73(\mathrm{~m}) \\
\text { D106 (p) } \\
\text { AE2 (m) } \\
\text { AKH1 (m) } \\
\text { AKH2 (m) } \\
\text { 3F6-6 (m) } \\
\alpha-54 \text { kD (p) }\end{array}$ & $\begin{array}{l}\text { EBV-VCA } \\
\text { EBV-EA(D) } \\
\text { P62 (human) } \\
\text { ck* } 5+8 \\
\text { epidermal ck } \\
\text { ck } 18 \\
\text { ck } 10 \\
\text { ck } 4 \\
\text { ck } 13 \\
\text { ck } 7 \\
\text { ck } 13+16 \\
\text { Vimentin } \\
\text { Lamins A, B, C } \\
\text { AB" (U snRNPs) } \\
B^{*} \text { (U snRNPs) } \\
\text { Sm (U snRNPs) } \\
70 \text { kD (U snRNPs) } \\
\text { Topoisomerase I } \\
\text { ck } 1 \text {, } 2,10,11+\text { filaggrin } \\
\text { Human filaggrin } \\
\text { KHG* epidermis } \\
\text { Rat filaggrin } \\
\text { Rat filaggrin }\end{array}$ & $\begin{array}{l}- \\
- \\
- \\
= \\
= \\
= \\
= \\
= \\
= \\
- \\
- \\
= \\
- \\
- \\
+ \\
++ \\
= \\
++\end{array}$ & $\begin{array}{l}\bar{z} \\
\overline{-} \\
\overline{-} \\
\bar{z} \\
\overline{+} \\
+ \\
\overline{+} \\
\overline{-} \\
\overline{-} \\
\overline{-} \\
\overline{-} \\
\bar{z} \\
\bar{z} \\
\bar{z} \\
\bar{z}\end{array}$ \\
\hline
\end{tabular}

*APF=antiperinuclear factor: $A K A=$ antikeratin antibodies; $m=$ monoclonal antibody; $p=p o l y-$ clonal antibody; ck=cytokeratin; KHG=keratohyalin granules. positive for antiperinuclear factor, and the results (figs $3 A$ and $B$ ) show that in every cell an exact colocalisation of the perinuclear factor and profilaggrin could be seen. This exact colocalisation of profilaggrin with the perinuclear factor suggests that these two proteins may be identical. This possibility was tested in several ways.

Firstly, competition of the binding of AKH1 (antifilaggrin) by increasing concentrations of antiperinuclear factor antibody did not abolish the binding of AKHl to the keratohyalin granules. Therefore another epitope of profilaggrin or another antigen is recognised.

Secondly, when extracts of buccal mucosa cells on a western blot were probed with AKH1 (fig 4, lane 1) a band of filaggrin ( $37 \mathrm{kD}$ ) appeared. (Profilaggrin is an unstable protein and easily degrades to filaggrin.) Most of the serum samples containing antiperinuclear factor, however, stained the filaggrin band only weakly
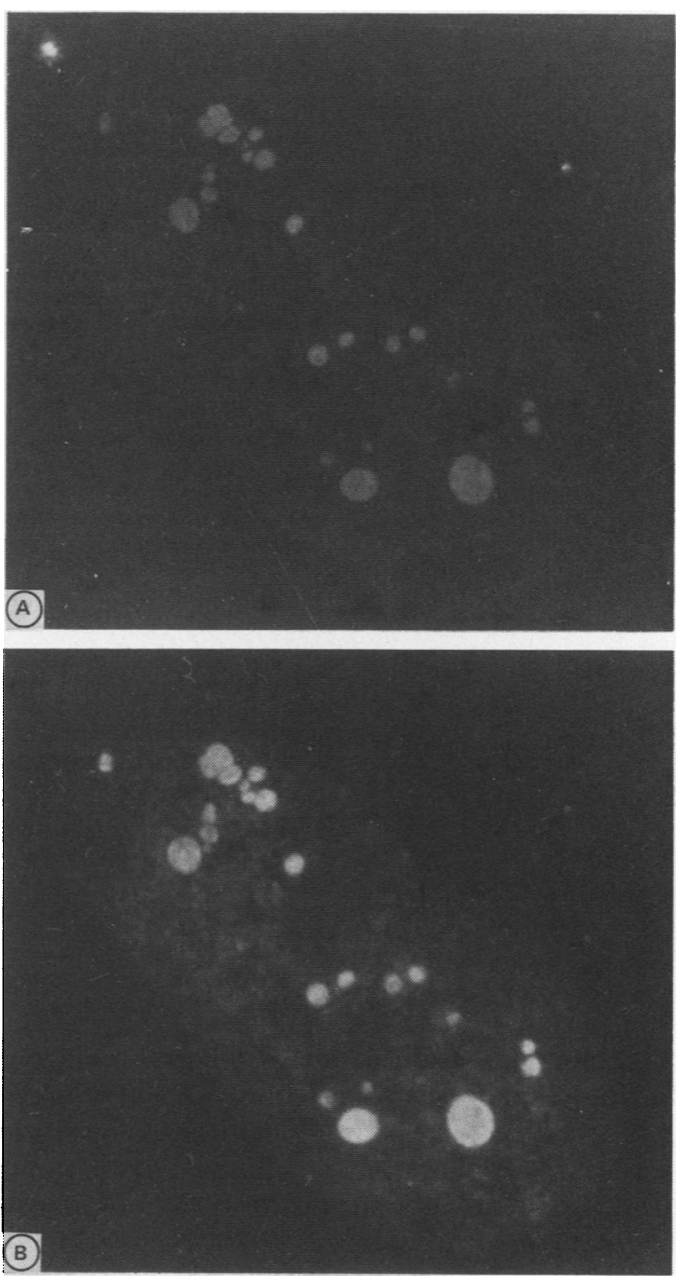

Figure 3 Colocalisation of the perinuclear factor and filaggrin. Buccal mucosa cells were incubated with serum positive for antiperinuclear factor (E10, diluted 1:50) for one hour followed by a 30 minute incubation with fluorescein isothiocyanate labelled rabbit antihuman immunoglobulin. Then the cells were incubated for 30 minutes with AKHI (monoclonal antibody against human (pro)filaggrin) followed by an incubation with Texas red labelled rabbit antimouse immunoglobulin. Between each incubation step cells were washed $3 \times 10$ minutes with phosphate buffered saline. Finally, preparations were mounted with glycerol/phosphate buffered saline (1:1). All possible combinations of antibody control incubations were included and were found to be negative. (A) Antiperinuclear factor pattern; (B) filaggrin pattern. 


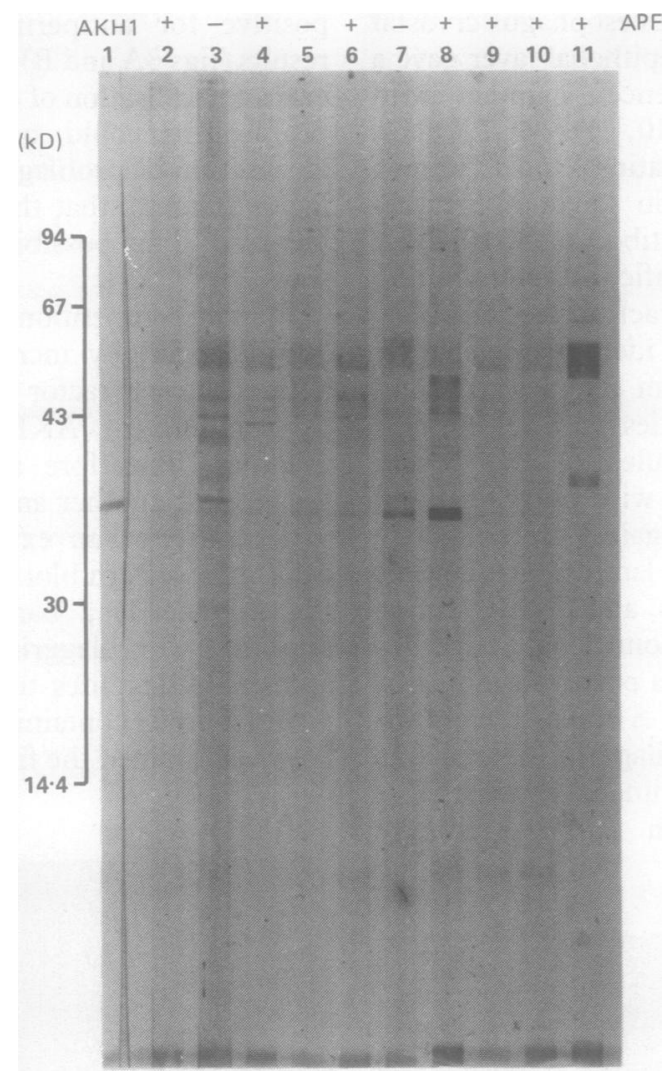

Figure 4 Serum samples from patients with rheumatoid arthritis tested on a buccal mucosa cell immunoblot. Protein blots containing an extract of buccal mucosa cells were incubated with antiperinuclear factor positive and negative serum samples (lanes 2 to 11). As positive control the monoclonal antibody AKH1, directed against human (pro)filaggrin was used (lane 1). Note that only the monoclonal antibody and one rheumatoid serum sample containing antiperinuclear factor $(K 36$, lane 8$)$ reacted strongly with filaggrin.

or not at all. In fact only one human serum sample (fig 4, lane 8) out of 30 tested reacted strongly with filaggrin. We did not find other protein band(s) on a western blot that reacted reproducibly with antiperinuclear factor antibody.

Thirdly, in immunofluorescence studies antibodies against (pro)filaggrin react with their antigen in keratohyalin granules of human foreskin keratinocytes, whereas antiperinuclear factor did not. Protein blots containing foreskin keratinocyte extract also did not react with serum samples containing antiperinuclear factor (data not shown). Apparently keratohyalin granules of keratinised epithelium (human foreskin) contain (pro)filaggrin but not the perinuclear factor. We conclude that the perinuclear factor is not identical with (pro)filaggrin, though in buccal mucosa cells both proteins have the same localisation.

\section{Discussion}

The antiperinuclear factor has been described as a specific serological marker for rheumatoid arthritis. In this study the original test ${ }^{19}$ was modified by pretreating the cells with Triton$\mathrm{X} 100$, which resulted in an increased sensitivity $(73 \%$ v $81 \%)$ while maintaining a high specificity compared with healthy controls (table 1). The main reason for the increased sensitivity is the fact that the detergent treatment increases the permeability of the cell membranes for the antibody while at the same time the cytoplasmic background staining is decreased because all soluble components of the cells (proteins, most ribosomes, tRNA) and residual mouth flora are removed.

With this modified technique we established that the perinuclear factor is present in buccal mucosa cells of most people and that finding a 'good' donor for buccal mucosa cells is probably not a major problem. We also noted that the antiperinuclear factor can be found in somewhat higher prevalences in serum samples from patients with other autoimmune diseases (table 2). Although the possibility that these patients may be in the process of developing rheumatoid arthritis (most marker autoantibodies have a prognostic character ${ }^{1}$ ) cannot be completely excluded, other studies have also indicated higher prevalences of antiperinuclear factor in the serum samples of patients with systemic lupus erythematosus, systemic sclerosis, and Sjögren's syndrome than in those of healthy controls. ${ }^{22} 233031$ Apparently the presence of antiperinuclear factor is not restricted to rheumatoid arthritis only.

Using an immunoelectron microscopical technique we confirmed that the perinuclear factor is localised in the keratohyalin granules of buccal mucosa cells (fig 2). The whole body of the poorly structured granule seemed to contain the antigen, supporting the idea that these granules are an amorphous mixture of densely packed proteins. Only treatment with proteolytic enzymes seems able to untangle and degrade this mass, whereas denaturing by fixatives renders it even more inaccessible for antibodies (table 5). Until now not much was known about the biochemical composition of the keratohyalin granules in buccal mucosa cells. We identified the protein (pro)filaggrin in these granules and found it to be colocalised with the perinuclear factor. Several experiments emphasised that the perinuclear factor is not identical with (pro)filaggrin. The exact biochemical nature of the perinuclear factor remains a mystery, therefore.

It probably is one antigen as all 10 serum samples containing antiperinuclear factor tested react with the antigen in granules of various donors. It is unlikely that the antiperinuclear factor is identical with a rheumatoid factor subclass $^{32}$ because $11 \%$ of our rheumatoid factor positive serum samples contained no antiperinuclear factor 'and $6 \%$ of the serum samples without rheumatoid factor did contain antiperinuclear factor (table 3). Other authors have also found serum samples without rheumatoid factor and with antiperinuclear factor in 4 to $18 \%$ of subjects. ${ }^{16192122262829}$

Westgeest et al found the antiperinuclear factor in $51 \%$ of patients with a recent EpsteinBarr virus infection, ${ }^{25}$ suggesting a relation between antiperinuclear factor and EpsteinBarr virus. We used several antibodies directed against Epstein-Barr virus proteins (VCA, EA(D), P-62), but none of them reacted with 
the keratohyalin granules in the buccal mucosa cells (table 6). A more likely possibility in our view is that the antiperinuclear factor is related to or identical with the antikeratin antibodyantigen. Both antigens for antiperinuclear factor and antikeratin antibodies are located in squamous epithelia. Not only is there a very good correlation between the occurrences of antikeratin antibodies and antiperinuclear factor (table 4) but all our serum samples containing antikeratin antibodies contained antiperinuclear factor antibody as well. The reverse is not true because the antiperinuclear factor test is more sensitive than the test for antikeratin antibodies. A certain overlap between antikeratin antibodies and antiperinuclear factor has also been reported by others. ${ }^{16} 2653$ We tested monoclonal and polyclonal antibodies against different keratins on buccal mucosa cells but could not find a specific reaction with the keratohyalin granules (table 6). The same antikeratin antibodies were also tested on rat oesophagus sections, which resulted in a positive staining of the epithelial layer for cytokeratins 4 and 13 (monoclonal antibodies 6B10, 2D7, and K8.12), which are known to be present in oesophagus squamous epithelium. Although identical immunofluorescence staining was obtained with the rheumatoid serum samples containing antikeratin antibodies, subsequent two dimensional immunoblotting of a rat oesophagus extract with these samples did not show specific positive reactions with cytokeratin 4 or 13 , whereas the monoclonal antibodies $(6 \mathrm{~B} 10,2 \mathrm{D} 7$, and $\mathrm{K} 8.12)$ did react. It therefore is questionable whether antikeratin antibodies recognise a cytokeratin as the antigen. It is more likely that the antikeratin antibodyantigen is a protein associated with the cytokeratins in this type of epithelial cell. The name 'antikeratin antibodies', therefore, seems a most unfortunate choice and it would be better to refer to them as antirat oesophagus antibodies.

The association of the perinuclear factor with (pro)filaggrin, a protein which up to now has only been found in differentiated keratinocytes, ${ }^{54}$ suggests a differentiation-specific expression of the perinuclear factor. Our future research, therefore, will be directed towards establishing an in vitro culturing system for buccal mucosa keratinocytes to study the differentiation of these cells and the in vitro induction of the perinuclear factor. ${ }^{55}$

We are grateful to Drs F Ramaekers, B Dale, G van Muijen, J Warren, P J W Venables, K Fukuyama, I A Bernstein, S O Hoch, J Steitz, and $W$ Habets for providing antibodies used in this study.

This study was financially supported by the Dutch Rheumatism Foundation.

1 Tan E M. Antinuclear antibodies: diagnostic markers for autoimmune diseases and probes for cell biology. Adv Immunol 1989; 44: 93-156.

2 Waller M V, Toone E C, Vaughan E. Study of rheumatoid factor in a normal population. Arthritis Rheum 1964; 7: 513-20;.

3 Kurki P, Helve T, Virtanen I. Antibodies to cytoplasmic intermediate filaments in rheumatic diseases. $\mathcal{F}$ Rheumatol 1983; 10: $558-62$.

4 Kataaha P K, Mortazavi-Milani S M, Russell G, Holborow E J. Anti-intermediate filament antibodies, antikeratin antibody, and antiperinuclear factor in rheumatoid arthritis and infectious mononucleosis. Ann Rheum Dis 1985; 44: 446-9.
5 Senecal J L, Rothfield N F, Oliver J M. Immunoglobulin M autoantibody to vimentin intermediate filaments. $\mathcal{J}$ Clin Invest 1982; 69: 716-21

6 Kurki P, Virtanen I. The detection of human antibodies against cytoskeletal components. F Immunol Methods 1984 67: 209-23.

7 Osung O A, Chandra M, Holborow E J. Intermediate filaments in synovial lining cells in rheumatoid arthritis and other arthritides are of the vimentin type. Ann Rheum Dis 1982; 41: 74-7.

8 Quismorio P F, Kaufman R L, Beardmore T, Mongan E S. Reactivity of serum antibodies to the keratin layer of rat Reactivity of serum antibodies to the keratin layer of rat Rheum 1983; 26: 494-9.

9 Toh B H, Sotelo Y J, Osung O, Holborow E J, Kanakoudi F, Small J V. Viral infections and IgM autoantibodies to cytoplasmic intermediate filaments. Clin Exp Immunol 1979; 37: 76-82.

10 Alcover A, Molano J, Renart J, Gil-Aguado A, Nieto A, Avila $J$. Antibodies to vimentin intermediate filaments in sera from patients with systemic lupus erythematosus. Arthritis Rhew 1984; 27: 922-8.

11 Osung $\mathrm{O}$ A, Chandra M, Holborow E J. Antibody to intermediate filaments of the cytoskeleton in rheumatoid arthritis. Ann Rheum Dis 1982; 41: 69-73.

12 Young B J J, Mallya R K, Leslie R D G, Clark C J M, Hamblin $T$ J. Antikeratin antibodies in rheumatoid Hamblin T J. Antikeratin antitis. BMF 1979; ii: 97-9.

13 Kirnstein $\mathrm{H}$, Mathiesen $\mathrm{K}$ F. Antikeratin antibodies in rheumatoid arthritis. Scand f Rheumatol 1987; 16: 331-7.

14 Youinou P, Le Goff P, Colaco C B, et al. Antikeratin antibodies in serum and synovial fluid show specificity for rheumatoid arthritis in a study of connective tissue diseases. Ann Rhewm Dis 1985; 44: 450-4.

15 Scott D L, Delamere J P, Jones L J, Walton $K W$. Significance of laminar antikeratin antibodies to rat oesophagus in rheumatoid arthritis. Ann Rheum Dis 1981; 40: $267-71$.

16 Johnson G D, Carvalho A, Holborow E J, Goddard D H, Russell G. Antiperinuclear factor and antikeratin anti-
bodies in rheumatoid arthritis. Ann Rheum Dis 1981; 40: bodies

17 Mallya R K, Young B J J, Pepys M B, Hamblin T J, Mace B E W, Hamilton E B D. Anti-keratin antibodies in rheumatoid arthritis: frequency and correlation with other features of the disease. Clin Exp I mmunol 1983; 51: 17-20.

18 Vincent $C$, Serre G, Lapeyre F, et al. High diagnostic value in rheumatoid arthritis of antibodies to the stratum coreum of rat oesophagus epithelium, so-called 'antikeratin antibodies'. Ann Rhewm Dis 1989; 48: 712-22.

19 Nienhuis R L F, Mandema E. A new serum factor in patients with rheumatoid arthritis. The antiperinuclear factor. Ann Rheum Dis 1964; 23: 302-5.

20 Smit J W, Sondag-Tschroots I R J M, Aaij C, Feltkamp T E W, Feltkamp-Vroom T M. The antiperinuclear factor. II. A light microscopical and immunofluorescence study on the antigenic substrate. Ann Rheum Dis 1980; 39: 381-6.

21 Westgeest A A A, Boerbooms A M Th, Jongmans $M$, Vandenbroucke J P, Vierwinden G, van de Putte L B A. Antiperinuclear factor: indicator of more severe disease in seronegative rheumatoid arthritis. F Rheumatol 1987; 14: 893-7.

22 Sondag-Tschroots I R J M, Aaij C, Smit J W, Feltkamp $T E W$. The antiperinuclear factor. 1. The diagnostic significance of the antiperinuclear factor for rheumatoid significance of the antiperinuclear factor for
arthritis. Ann Rheum Dis 1979; 38: 248-51.

23 Youinou P, Pennec Y, Le Goff P, Ferec C, Morrow W J W, Le Menn G. Antiperinuclear factor in Sjögren's syndrome in the presence or absence of rheumatoid arthritis. Clin Exp Rheumatol 1984; 2: 5-9.

24 Youinou P, Zabba C, Eveillaud C, et al. Antiperinuclear activity in lung carcinoma patients. Cancer Immunol Immunother 1984; 18: 80-1.

25 Westgeest A A A, van Loon A M, van der Logt J T M, van de Putte L B A, Boerbooms A M Th. Antiperinuclear factor, a rheumatoid arthritis specific autoantibody: its relation to Epstein-Barr virus. F Rheumatol 1989; 16: 626-30.

26 Youinou P, Le Goff P, Miossec P. Untersuchungen zur beziehung zwichen antiperinucleären factoren, antikeratin-antikörpern und dem agglutinierenden und nich agglutinierenden rheumafactor bei der chronischen polyarthritis. $Z$ Rheumatol 1983; 42: 36-9.

27 Westgeest A A A, Boerbooms A M Th, van de Putte L B A. Rheumatoid arthritis and autoantibodies: a review of the literature on antinuclear antibody and antiperinuclear factor. University of Nijmegen, The Netherlands, 1988. (Thesis.)

28 Janssens X, Veys E M, Verbruggen G, Declercq L. The diagnostic significance of the antiperinuclear factor for rheumatoid arthritis. $\mathcal{F}$ Rheumatol 1988; 15: 1346-50.

29 Marmont A M, Damasio E E, Bertorello C, Rossi F. Studies on the antiperinuclear factor. Arthritis Rheum 1967; 10: $117-28$

30 Vivino F B, Maul G G. Antiperinuclear factor prevalence in rheumatic diseases [abstract]. Arthritis Rheum 1989; 32: S95.

31 Scherbaum W A, Youinou P Y, Le Goff P, Bottazzo G F. Anti-perinuclear and rheumatoid factor in different forms of autoimmune thyroid disease. Clin Exp Immunol 1984; 55: $516-8$.

32 Youinou P, Le Goff P, Casburen-Budd R, Ferec C, Pennec $Y$. Evidence for relationships between antiperinuclear and IgG rheumatoid factor. Rheumatol Int 1984; 4: 111-4.

33 de Rooij D L, van de Putte L B, Habets W J, Verbeek A L, 
van Venrooij $W \mathrm{~J}$. The use of immunoblotting to detect antibodies to nuclear and cytoplasmic antigens. Scand $\mathcal{F}$ Rheumatol 1988; 17: 353-64.

34 Ramaekers F C S, Huysmans A, Schaart G, Moesker O, Vooijs P. Tissue distribution of ketatin 7 as monitóred by a monoclonal antibody. Exp Cell Res 1987; 170: 235-49.

35 Ramaekers F C S, Huysmans A, Moesker O, et al. Monoclonal antibodies to keratin filaments specific for glandular clonal antibodies to keratin filaments specific for glandular epithelia and their tumors.

36 Ramaekers F C S, Puts J J, Moesker O, et al. Antibodies to intermediate filament proteins in the immunohistochemical identification of human tumours: an overview. Histochem $\mathcal{f}$ 1983; 15: 691-713.

37 van Muijen G N P, Ruiter D J, Franke W W, et al. Cell type heterogeneity of cytokeratin expression in complex epithelia and carcinomas as demonstrated by monoclonal antibodies specific for cytokeratins nos. 4 and 13. Exp Cell Res 1986; 162: 97-113.

38 Burke B, Tooze J, Warren J. A monoclonal antibody which recognizes each of the nuclear lamin polypeptides in recognizes each of the nuclear lamin poly

39 Dale B D, Gown A M, Fleckman P, Kimball J R, Resing K A. Characterization of two monoclonal antibodies to human epidermal keratohyalin: reactivity with filaggri and related proteins. $\mathcal{f}$ Invest Dermatol 1987; 88: 306-13.

40 Murozuka T, Fukuyama K, Epstein $W$ L. Immunochemica comparison of histidine-rich protein in keratohyalin ranules and cornified cells. Biochim Biophys Acta 1979; 579: 334-45.

$41 \mathrm{Kim} \mathrm{H}-\mathrm{J}$, Bernstein I A. Exposure to 12-0-tetradecanoylphorbol-13-acetate (TPA) induces the synthesis of histidinerich protein (filaggrin) in monolayer cultures of rat kerarich protein (filaggrin) in monolayer cultures

42 Woodcock-Mitchell J, Eichner R, Nelson W G, Sun T-T. Immunolocalization of keratin polypeptides in huma epidermis using monoclonal antibodies. $\mathcal{F}$ Cell Biol 1982; 95: 580-8.

43 Lazarides E. Intermediate filaments: a chemically heterogenous developmertally regulated class of proteins. An Rev Biochem 1982; 51: 219-50.

44 Billings P B, Allen R W, Jensen F C, Hoch S O. Anti-RNP monoclonal antibodies derived from a mouse strain with lupus-like autoimmunity. F Immunol 1982; 128: 1176-80.

45 Lerner E A, Lerner M R, Janeway C A, Steitz J A

Monoclonal antibodies to nucleic acid-containing cellular constituents: probes for molecular biology and autoimm disease. Proc Natl Acad Sci USA 1981; 78: 2737-41.

46 Habets W J , Hoet M H, de Jong B A W, van der Kemp A van Venrooij $W$ J. Mapping of B cell epitopes on small nuclear ribonucleoproteins that react with human automonoclonal antibodies. F Immunol 1989; 143: 2560-6.

47 Klein K, Bronsveld W, Norde W. A modified latex fixation test for the detection of rheumatoid factor. $\mathcal{f}$ Clin Pathol 1979; 32: 90-2.

48 Fleckman P, Dale B A, Holbrook K A. Profilaggrin a high molecular-weight precursor of filaggrin in human epidermis and cultured keratinocytes. F Invest Dermatol 1985; 85: 507-12.

49 Laemmli U K. Cleavage of structural proteins during the assembly of the head of bacteriophage T4. Nature 1970; 227: $680-5$

50 Habets W J, De Rooij D J, Salden M H, et al. Antibodies against distinct nuclear matrix proteins are characteristic or mixed connective tissue disease. Clin Exp Immunol 1983; $54: 265-76$.

S1 Habets W J, de Rooij D J, Hoet M H, van der Putte L B, van Venrooij W J. Quantitation of anti-RNP and anti-Sm antibodies in MCTD and SLE patients by immunoblotting. Clin Exp Immunol 1985; 59: 457-66.

52 Ruiter D J, Mauw B J, Beyer-Boon M E. Ultrastructure of normal epithelial cells in Papanicolaou-stained cervical normal epithelial cells in Papanicola

53 Miossec P, Youinou P, Le Goff P, Moineau M P. Clinical relevance of antikeratin antibodies in rheumatoid arthritis. Clin Rheumatol 1982;1: 185-9.

54 Dale B A, Holbrook K A, Kimball J R, Hoff M, Sun T-T. Expression of epidermal keratins and filaggrin during fetal skin development. F Cell Biol 1985; 101: 1257-69.

55 Hoet R M, Voorsmit R A C A, van Venrooij W J. The perinuclear factor, a rheumatoid arthritis-specific autoantigen, is not present in keratohyalin granules of cultured buccal mucosa cells. Clin Exp Immunol 1991; 84: 59-65. 